素酸に 99\% 濃硫酸を滴下し，発生するガスを上と同樣に乾燥，精製して用いてもよい。

（2）過剩の臭化水素ガスを吹込みすぎると開環生成物を生じ，収率低下の原因となる。

\title{
III. 性質
}

bp $74^{\circ} \mathrm{C} / 4 \mathrm{mmHg}, 108^{\circ} \mathrm{C} / 22 \mathrm{mmHg}, d_{4}^{20} 1.3232, n_{\mathrm{D}}^{23} 1.4818$. エーテル, エタノール，クロロホルムなどの有機溶媒 に可溶, 水に不溶。長く保存すると淡黄色からカッ色変色する。

\section{IV. 本法の利点}

従来の合成法として 3-(2-tetrahydrofuryl)propanol をエーテル溶媒中で三臭化リン゙)，無水臭化水素ガス5゙あるけ 臭化水素酸堂,5)を使用する方法が知られ，本法は Szarvasi ら ${ }^{5}$ の方法を改良し，収率の向上をはかったものである。

1) 木村, 加藤, 角, 有合化 22930 (1964)

2) Org. Synth. Coll. Vol. 2338 (1943)

3) 木村, 山本, 丹羽, 有合化 22936 (1964)

4) C.S. Hornberger et al., J. Am. Chem. Soc. 751275 (1953)

5) E. Szarvasi, G. Qupont, R. Dulon, Chim \& Ind 62143 (1949) [C.A. 445345 (1950); FP. 958, $267(1950)]$

\section{1, 4-Dichloroanthraquinone}

提案者 松 本 好 和

(群馬大学工業短大部)

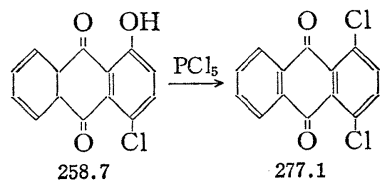

\section{I. 製 法}

$500 \mathrm{ml}$ のナス型フラスコに空気冷却管（注 1 ） をつけ，これに o-ジクロルベンゼン $250 \mathrm{~g}$, 五塩化リン $31.24 \mathrm{~g}(0$. $15 \mathrm{~mol}$ ) および 4-chloro-1-hydroxyanthraquinone（注 2 ) $25.87 \mathrm{~g}(0.1 \mathrm{~mol})$ を入れ，鉄網上で募沸還流させる。のち 水 $300 \mathrm{~m} l$ を入れた $1 l$ の丸底フラスコに反応液を入れ, 水蒸気蒸留により $o$-ジクロルベンゼンを留去する。ついでフ ラスコを泠し，固化した残留物を吸引口過する。これを乳鉢で細粉化し，さらに水蒸気蒸留により完全に 0 -ジクロル ベンゼンを除く。得られた粗生成物を吸引口過し, 温水洗, 乾燥（粗品収量 $27.35 \mathrm{~g}$ ) したのち, 少量の活性炭を使い

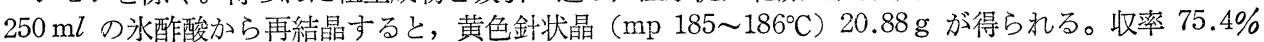

\section{II. 注意事 項}

（1）冷却管の上部に塩化カルシウム管をつけ，その先端をゴム管でつなぎ，塩酸ガスを流水中に導くようにする。

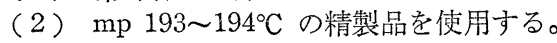

\section{III. 性質}

黄色針状晶。 $\mathrm{mp} 185 \sim 186^{\circ} \mathrm{C} ; 186^{\circ} \mathrm{C}^{1)} ; 187.5^{\circ} \mathrm{C}$ (補正 $)^{2)} ; 187.5 \sim 188^{\circ} \mathrm{C}^{3)}$ 。トロベンゼン，ピリジンによくとけ る。熱時ベンゼン氷酢酸にとけるが，エーテル，アルコール，リグロインにはとけにくい。

\section{IV. 本法の利点}

本合成には，4-chloro-1-hydroxyanthraquinone を五塩化リンと加熱する法4,5), 2-(2,5-dichlorobenzoyl)-benzoic acid と濃硫酸3,6)またはホウ酸の存在中，10\% 発煙硫酸当と加熱する法および 3,6-dichloro-2-benzoyl benzoic acid の 脱水による法 ${ }^{2,7)}$ などがある。文献 1),3)，6）記載の方法は dichlorobenzoyl benzoic acid 自身に問題があり，合成が 困難である。本法は比較的容易に得られる 4-chloro-1-hydroxyanthraquinone ${ }^{8)}$ から文献 4)5) 記載の過激な方法を検 討し，希釈剤として $o$-ジクロルベンゼンを用いて行なったものである。

\section{引用文献}

1) G.M. Walsh, C. Weizmann, J. Chem. Soc. 97687 (1910)

2) F. Ullmann, G. Billg, Ann. 38115 (1911)

3) G. Egerer, H. Meyer, Monatsh. 3490 (1913)

4) Akt. F. Anilinfab., DRP 290, 879 (1914); Friedl., 12409 (1917)

5) F. Ullmann, A. Conzetti, Ber. 53832 (1920)

6) M. Phillips, J. Am. Chem. Soc. 483199 (1926)

7) C. Graebe, Ber. 332019 (1900)

8）内木，有機化合物合成法，第 10 集，p 57 